\title{
Refreny uchodźcze w poezji Nelly Sachs
}

\author{
Refugees' Refrains in the Poetry by Nelly Sachs
}

\author{
|| Joanna Roszak
}

\begin{abstract}
In the article I have been studying what premises constitute in the work of this German-speaking Nobel Prize winner and how the author brings the wounded world to the poem. I am aiming at interpreting her works in the relation to the refugees theme. I read her neurotic poetry also in the context of the contemporary nomadological discourse and I perceive it as a signpost to the language of solidarity. In the works of the Nobel Prize winner from 1966 one can see a preview of the style of the poems written by contemporary refuges (Breyten Breytenbach or Ashur Etwebi), and the artistic community of people deprived of their homes. I close the article with the conclusion related to the use of poetry in education for peace.
\end{abstract}

Key-words: poetry, education for peace, Nelly Sachs

Streszczenie: W artykule badam, jaki zespół przesłanek konstytuuje się w twórczości niemieckojęzycznej noblistki oraz w jaki sposób autorka sprowadza do wiersza zraniony świat. Interpretuję jej utwory związane z wątkiem uchodźczym. Czytam jej neurotyczną poezję także w obrębie współczesnego dyskursu nomadologicznego i postrzegam jako drogowskaz ku językowi solidarności. W twórczości noblistki z 1966 roku można dostrzec zapowiedź stylistyki współczesnych wierszy uchodźców (m.in. Breyten Breytenbach czy Ashur Etwebi), buduje się wspólnota artystyczna osób pozbawionych domu. Artykuł zamykam konkluzją związaną z wykorzystaniem poezji w edukacji na rzecz pokoju.

Słowa kluczowe: poezja, edukacja na rzecz pokoju, Nelly Sachs

Zostałem pisarzem także dlatego, że pochodziłem z rodziny zrozpaczonych uchodźców.

(Oz 2010, 11)

Milczymy o wygnańcach naszych czasów

(...) Przez nasze sny i dusze

jadą transporty wygnańców.

(Bierezin 1990, 15) 
Twój bagaż uchodźcy masz już

po drugiej stronie -

granica jest otwarta

lecz przedtem

oni wyrzucą wszystkie twoje „w domu”

jak gwiazdy przez okno

(Sachs 2006, 211) ${ }^{1}$

\section{To jest uchodźców planetarna godzina}

21 grudnia 1957 roku w liście do Paula Celana Nelly Sachs pisała ze Sztokholmu: „Zna Pan moje rzeczy, ma je Pan u siebie, więc mam swój dom” (Celan, Sachs 1994, 139). 9 stycznia kolejnego roku doceniona poetka, która nadal wśród najważniejszych samookreśleń tożsamościowych wskazywała na bycie uchodźczynią, zwracała się do niego: „Właściwie moje książki błąkały się dotąd jako sieroty. (...) muszę się teraz dopiero przyzwyczaić do radości po tylu cierpieniach, i kiedy poeci szwedzcy w dzień Nowego Roku przekazywali mi swoją właśnie ufundowaną nagrodę poetycką, po prostu nic z tego nie rozumiałam i zupełnie się zagubiłam, mnie obcojęzycznemu uciekinierowi, taki zaszczyt" (Celan, Sachs 1994, 141-142).

Nelly Sachs urodziła się w Berlinie w 1891 roku, zmarła w 1970 w Sztokholmie. W 1940 roku wraz z matką uszła przed Zagładą do Szwecji, a w 1966 roku została uhonorowana Nagrodą Nobla w dziedzinie literatury. Wiersze stały się dla niej epitafium dla sześciu milionów zgładzonych Żydów. W sztokholmskim mieszkaniu Sachs założyła elegijny ogródek kamieni (Zimmersteingarten), muzeum śladów, miniaturowy cmentarz. O kamykach i muszlach jej biograf, Aris Fioretos, napisał: „były kamieniami nagrobnymi" (Fioretos 2010, 113).

Poetka nie tylko wspominała ofiary, ale także przeciwstawiała się przemocy. Zwykle odczytuje się jej poezję w kontekście możliwości pisania po Auschwitz i stworzenia nowego języka, zwiększania ekspresji poetyckiej i budowania światowej solidarności. Jej gorzkie i zmetaforyzowane wiersze, wykarmione drogą i obcym miejscem, mają związek z językiem Biblii Hebrajskiej, mistyką chrześcijańską i tradycją żydowską. Jak napisała Katherin M. Bower, poezja stała się dla Nelly Sachs przestrzenią „rekonwalescencji i refleksji” (recuperation and reflection) (Bower 2000, 2). Katja Garloff dostrzegała w jej twórczości sferę „rekoncyliacji między Niemcami i Żydami” („reconciliation between German and Jews”) (Garloff 2005, 1) i zauważała, że Sachs konstruowała symboliczną przestrzeń, w której biblijne nazwy pozwalały jej odtwarzać konflikty między tym, co niemieckie i tym, co żydowskie oraz umożliwiały obmyślanie strategii przetrwania (Garloff 2005, 11) $)^{2}$.

\footnotetext{
${ }^{1}$ Cytując dalej za tym wydaniem, używam skrótu SK i wskazuję numer strony.

2 ,She constructs symbolic spaces in which biblical place names such as Ur come to encapsulate her own conflict between German and Jewish origin, a survival strategy". 
Owe konflikty rozgrywały się także na płaszczyźnie najbardziej prywatnej - poetka identyfikowała się z drugim imieniem, Sara, noszonym przez nią po żonie Abrahama i matce Izaaka, pramatce Izraela (Jennifer M. Hoyer 2014). Jej wiersze, kwintesencja tego, co można by nazwać poetycką autobiografią, nigdy nie zapomniały lat terroru w Trzeciej Rzeszy (Patterson, Berger, Cargas 2002, Rose 2008). Jean-Luc Nancy artykuł Zakazana reprezentacja otworzył wierszem Wir sind die Letzten (H. Sal) z kodą: „tylko w wierszu można wypowiedzieć to, co opis ośmiesza" (Nancy 2004, 113, Martin 2014). Nic dziwnego że jako pierwszy utwór, mający potwierdzić tezę jego artykułu, francuski filozof przywołał Twoje ciało $z$ dymem ulatuje Nelly Sachs.

Hermann Korte zakwalifikował jej twórczość do poezji hermetycznej (Hermetismus). W rozdziale Gegenwort und Flaschenpost do tego rodzaju liryki zaliczył także wiersze Arendt, Bachmann, Bobrowskiego, Celana i Huchla (Korte 2012, 33). Po ucieczce Sachs do Szwecji jej utwory stały się wierszami-listami w poczcie butelkowej (choć określenie Flaschenpost kojarzy się raczej z mową Paula Celana: „Wiersz, będąc formą przejawiania się języka, ze swej istoty jest czymś dialogowym, może więc być pocztą butelkową, wysłaną w tej - z pewnością niezbyt mocną w nadzieję, wierze, że kiedyś tam przybije do jakiegoś brzegu, być może w kraju serca") (Celan 1998, 317). Nie te teksty, które dotykają doświadczenia obozów, Sachs obcego, choć współczująco wyobrażonego, ale te związane z ucieczką oraz zachodzącą podczas niej i po niej przemianą oraz z uchodźstwem staną się przedmiotem mojej refleksji (Buryła 2016, 49) ${ }^{3}$. Nieuchronne przesunięcie ku dzisiejszej sytuacji uchodźczej wydaje się konstruktywne, a dla poezji Sachs aktualizujące (Evelein 2014, 166).

Sama tworzona po niemiecku poezja autorki Roż̇arzonych zagadek także była uchodźczynią, cieniem ojczyzny, ale jednocześnie - azylem. Sachs pisała do Paula Celana: „Alle Worte Flüchtlinge” („wszystkie słowa są uciekinierami"). Odpryski skażonej niemczyzny kompulsywnie wypierała w poezji. Inny noblista, Czesław Miłosz, który status uchodźcy uzyskał w 1951 roku we Francji, patrząc po latach na Zatokę San Francisco, porównał pisanie tam po polsku do ukrywania słów w dziuplach drzew. Sachs, spoglądając na Zatokę Saltsjön nad Morzem Bałtyckim, mogłaby wypowiedzieć się podobnie.

Zaczytywała się w Cudownej podróży Selmy Lagerlöf, do której to autorki napisała wnet po debiucie w 1921 roku i która po latach pomogła jej w ucieczce. Ciekawe, że książkę Szwedki wspomniała również Alona Frankel, dziewczynka uratowana z lwowskiego getta, obecnie autorka i ilustratorka książek dla młodszych odbiorców:

${ }^{3}$ Oglądając fotografie Nelly Sachs, przypominam sobie to zdanie z książki Sławomira Buryły: „zły wygląd to nie tylko cechy fizyczne - również coś mniej uchwytnego, owe «smutne i przestraszone oczy»" (Buryła 2016, 62). 
Później, kiedy miałam już dwanaście i pół roku, poznałam mądrego Marcina, gąsiora Nilsa Holgerssona. Nie przypominał moich gęsi, ptaków głupich i złośliwych. O Nilsie Holgerssonie i gąsiorze Marcinie opowiadała Selma Lagerlöf w grubej książce z ilustracjami Jana Marcina Szancera. Książkę tę dała mi w prezencie mama w przeddzień naszego wyjazdu z Polski do Palestyny (Frankel 2007, 22).

Nelly Sachs wyruszyła do Szwecji 16 maja 1940 z berlińskiego lotniska Tempelhof, z brązową walizką o wymiarach 74x21x44 cm (Fioretos 2010, 50). Wyjeżdżały z matką w wielkim pośpiechu, jak wspominała Gudrun Dähnert: „Szybkie uściski starczyły za pożegnanie” (cyt. za: Dinesen 1992, 111). Aris Fioretos dał wgląd w zawartość walizki:

pięć marek, które powinny nosić, termos z herbatą koperkową dla chorej matki i zawartość brązowej walizki (...). Bagaż został związany dwoma skórzanymi pasami i zawierał, oprócz odzieży, rękopisów i fotografii, serię przedmiotów sentymentalnych - między nimi order ojca, pudełeczko i album opłatków. List do Ministerstwa Finansów na początku miesiąca ujawnia, że główny urząd celny opuściły: 2 lampki na stoliki nocne, 1 sukienka letnia, 2 medale, kolejna letnia sukienka, 110 książek, rękopisy (Fioretos 2010, 110).

Spakowała do walizki to samo, co w wierszu enumerowała Jenifer Toksvig (What they took - a list), korzystając ze świadectw współczesnych uchodźców i uchodźczyń: portfel, świadectwo ukończenia szkoły, klucze do domu, zdjęcie rodzinne. Także Stanisław Barańczak w Jeżeli porcelana, to wyłacznie taka opisał ich doświadczenie (Barańczak 2006, 218).

Sachs, pochodząca z asymilowanej rodziny żydowskiej, wierzyła, że przodkowie ze strony ojca uciekali w XV wieku od pogromów w Hiszpanii (Dinesen 1992, 95). Pozostawiła w Berlinie wyszukaną porcelanę, wygodny fotel, suknie i bluzki, plany, zostawiła miasto, ulicę, dom, przyzwyczajenia, język (Hoyer 2014).

Nie znała nowego języka, nie znała Szwedów. Cudowna podróż w pokrętny sposób stała się dla niej - jak mówiła podczas uroczystości noblowskiej - rzeczywistością. W Szwecji Sachs na nowo zajęła się chasydyzmem. Rachel Elior, badaczka żydowskiego mistycyzmu, zauważyła: „Doświadczenie wygnania i tęsknota za zbawieniem nie zawsze zyskiwały równe natężenie - słabły i nasilały się w różnych czasach. Im większe było cierpienie wygnania, tym silniejsze było pragnienie zbawienia" (Elior 2009, 47). Poetka zaczęła pisać $\mathrm{w}$ przestrzeni diaspory, w krajobrazie ujścia. Uchodźstwo i gościnność to ważne komponenty jej tożsamości, a zarazem motywy jej wierszy.

Temat uchodźstwa, będący doświadczeniem Nelly Sachs, wzbierał w jej poezji po wyjeździe z Niemiec. Pojawił się także w wierszu, w którym "ty” lirycznym jawi się utracony ukochany poetki; podmiot namyśla się, na czym spoczęło jego ostatnie spojrzenie. Czy na ziemi, stającej się ziemią uchodźców? To zresztą jeden z polskich akcentów biografii Sachs, która poznała 
owego mężczyznę, gdy w 1908 roku przebywała z rodzicami w uzdrowisku w Reinerz (obecnie Duszniki Zdrój) ${ }^{4}$.

Gdybym tylko wiedziała,

Na czym spoczywało twoje ostatnie spojrzenie.

Czy był to kamień, który pił już wiele

Ostatnich spojrzeń, aż oślepione

Padały na ślepca?

Czy też była to ziemia,

Wystarczająca na tyle, by wypełnić but,

Całkiem czarna

Od tylu pożegnań

I od tylu zgotowanych śmierci? (SK, 23)

Także narody ziemi, narody tułaczy stają się odbiorcami jej wierszy. Kolejny utwór-apel, zarówno do bezpiecznych narodów, jak i do tych, które skazano na pomieszanie języków, oparła Sachs na figurze zaklęcia.

Narody ziemi,

które siłą nieznanych gwiazdozbiorów

owijacie się jak szpulki nićmi,

które zszywacie i prujecie na nowo, co zszyte,

które wchodzicie w pomieszanie języków

jak do pszczelego ula,

żeby się wkluwać w słodycz

i wystawiać na użądlenie -

Narody ziemi,

nie niszczcie wszechświata słów,

nie rozcinajcie nożem nienawiści

dźwięku, który się zrodził jednocześnie z oddechem. (SK, 47)

Gdy wybiła godzina śmierci i ucieczki, gdy poetka została wykarmiona - posługuję się obrazem z niżej cytowanego wiersza - czarnym jabłkiem poznania, zaczęła pisać. Uchodźcy i uchodźczynie zostają porównani do zwierzyny, kryjącej się przed myśliwym.

To jest uchodźców planetarna godzina.

To jest uchodźców rwąca ucieczka

w konwulsje, w śmierć!

To jest spadanie gwiazd z magicznego uwięzienia przez próg, przez piec, przez chleb.

To jest czarne jabłko poznania,

${ }^{4}$ Wiesław Rosocha na forum miłośników Dusznik-Zdroju napisał: „Na lewym skrzydełku okładki widzimy śliczną młodą dziewczynę w białej koronkowej bluzce i w słomkowym kapeluszu z wywiniętym rondem. Szczupła, czarnowłosa, w dłoni trzyma kwiat. Uosobienie delikatności, powagi i melancholijnego wdzięku. Zdjęcie pochodzi z 1907 albo 1908 roku, być może zrobiono je w uzdrowisku Reinerz. Nelly Sachs ma szesnaście, siedemnaście lat i już wkrótce pozna jedyną, wielką i niespełnioną miłość swojego życia". Cytuję za prywatnym listem od Autora (z 16 sierpnia 2017).

\section{Polonistyka. Innowacje}


ten lęk! Zgasłe słońce miłości,

co płonie! O jest kwiat popłochu,

zlany potem! To są myśliwi

$\mathrm{z}$ niczego, tylko z ucieczki.

To są ścigani, którzy swoje śmiertelne kryjówki

unoszą do grobów.

To jest piasek, przerażony,

z girlandami pożegnania.

To jest wypad ziemi pod gołe niebo,

jej zdyszany oddech

w pokornym powietrzu. (SK, 51)

Uchodźcom, którym $\mathrm{w}$ tej poezji przypisana została figura ryby, odjęto głos, wyrzuceni z pierwotnego środowiska - stali się bezbronni („Kiedy nadszedł wielki strach / stałam się niema”, SK, 155). Poetka zniekształca pole semantyczne, nakłada na siebie ugruntowane obrazy, tworząc nową jakość. Z głębi planu wydobywa się sygnał uchodźstwa. Wiersz wyraża prośbę o światło, miłosierdzie, solidarność. Sachs opisuje śmiertelne przesunięcia: mórz w piasek, piasku w kamień.

Tu i tam trzeba latarnię miłosierdzia

zanieść rybom,

którym ofiarowuje się połykanie haczyka

lub uduszenie się na piasku. (SK, 59)

Enumeracyjna anafora „ile” z następnego utworu w zazębionych wersach zmierza do ukazania samotności jako zaczynu wiersza, a kulminacją konfrontacji z samotnością okazuje się pamięciowe-tekstowe spotkanie $\mathrm{z}$ „ty”.

Ile mórz zabłąkanych w piasku,

ile piasku twardo wymodlonego w kamieniu,

ile czasu wypłakanego w śpiewny róg

muszli,

ile śmiertelnego osamotnienia

w perłowych oczach ryb,

ile porannych trąbek w koralu,

ile gwiezdnych wzorców w krysztale,

ile zarodków śmiechu w gardle mewy,

ile nici tęsknoty za domem

wędrujących po nocnych orbitach gwiazd,

ile żyznej ziemi

dla korzeni słowa:

Ty -

Ze wszystkimi wyłamanymi kratami

tajemnic

Ty - (SK, 75) 
Podmiot znajduje się na tropie prawa do ojczyzny, śledzi ją po omacku. Ta pozbawiona pierwotnego miejsca poezja poddaje się raczej lekturom geopoetycznym niż geokrytycznym. Ruth Dinesen zauważyła, że napisane po ucieczce Schwedischen Elegien - z dominującymi opisami wiatru i morza - przynależą do Naturlyrik (Dinesen 1992, 120). Dodawała: „Takie pojęcia, jak południk, równik, (...) emigracja jako azyl, ucieczka jako dom: to obrazy nowej tożsamości w późnej poezji [Sachs]" (Dinesen 1992, 345)5.

Poniższy utwór warto odczytać w sąsiedztwie aforyzmu Tymoteusza Karpowicza: „Nie da się otworzyć świata szerzej niż ludzkich ramion” (Karpowicz 1999, 281). Wiele elementów wiersza (geografia lądów, przemierzanych pod osłoną nocy, poszukiwanie otwartych ramion) buduje skojarzenie z drogą krzyżową.

Jestem na tropie swojego prawa do ojczyzny

tej geografii nocnych lądów

gdzie do miłości otwarte ramiona

zwisają ukrzyżowane na stopniach szerokości

w bezdennym oczekiwaniu - (SK, 177)

Przeniesienie ojczyzny w innym wierszu Sachs zostaje porównane do transfuzji krwi, Bóg także ma w nim cechy uchodźcy - pojawia się tu motyw radykalnej teodycei, a przez wspomnienie wygnańczych wysp wiersz Sachs wywołuje także obrazy z Ellis Island czy Lampedusy.
Zapadający się
orszak przodków z pochodniami
w ogrodach hyzopu lśniły ich głowy
w kryjówkach krwi uchodźcy Boga
Na wybrzeżach północnej godziny
na wygnańczych wyspach
chrzczeni wiatrowskazami gromu
agonia w płonących świątyniach
wasza ojczyzna przeniesiona w me żyły -
Jestem bogata jak morze
z przeszłości i z przyszłości
i cała ze śmiertelnej materii
śpiewam waszą pieśń - (SK, 181)

\section{Wiersze pełne historii}

Joachim Sartorius w wierszu Odwiedziny u wygnanej poetki, wydrukowanym w przekładzie Ryszarda Krynickiego w zbiorze Zegar szronu, ukazał Ilse Blumental-Weiss w konstelacji między innymi z Nelly Sachs: inną poetką mierzącą się z pisaniem po niemiecku za granicą Niemiec. Aleksandra Ubertowska konstatowała przecież: „w pełni owo beznadziejne

\footnotetext{
5 „Begriffe wie Meridian, Äquator (...), Exil als Asyl, Flucht als Heimat sind in ihrer späten Dichtung Bilder für ein neues Identitätsganzes”.
} 
i nieodwołalne uwikłanie opisali poeci, tacy jak Nelly Sachs czy Paul Celan" (Ubertowska 2002, 129). W jednym z wierszy noblistka zapisała:

Trudna miłość do kraju,

(...) W ucieczce z kraju

z ciężkim bagażem miłości. (SK, 87)

„Jej oczy były pełne jej historii” (Sartorius 2017, 55) - przeczytamy o Blumental-Weiss w wierszu Sartoriusa. Sachs można by poświęcić te same słowa. Współczesny niemiecki poeta kontynuuje opowieść o swojej bohaterce, innej berliniance $\mathrm{z}$ urodzenia, ocalonej między innymi z obozu w Theresienstadt, emigrantce do Nowego Jorku:

W tym mieszkaniu w Jackson Heights, na Brooklynie opowiadała mi o Niemczech.

Nazywała je „mój były kraj”.

Opowiadała o swoich spotkaniach

z Else Lasker-Schüler (w Berlinie),

z Leo Baeckiem (w obozie koncentracyjnym w Theresienstadt),

z Nelly Sachs (w Sztokholmie) (...).

Nelly Sachs, przyjaciółka, pieszczotliwie nazywana „Li”

była „naznaczona cierpieniem”, to jej słowa, jak jej własne życie,

lecz jednak także pogodą ducha (Sartorius 2017, 56).

Pisarstwo Sachs prawdziwie wybuchło, gdy migrowała, bliska pięćdziesiątych urodzin. Tom poetycki In den Wohnungen des Todes wydała w roku 1947, a mieszkania uchodźców okazują się w nim mieszkaniami śmierci. W mowie podczas bankietu noblowskiego, 10 grudnia 1966 roku, wspominała, jak latem 1939 jej niemiecka przyjaciółka udała się do Szwecji, by odwiedzić Selmę Lagerlöf i prosić ją o pomoc dla Sachs i jej matki. Anders Olsson zauważył, że motyl to dla Nelly Sachs atrybut z jej mitologii doświadczenia ucieczki (Ronne 2011, 209), że poetka uczyniła go alegorią nomadyzmu. W Sztokholmie wyrecytowała wiersz In der Flucht ( $W$ ucieczce), z inklinacją tego toposu.

W ucieczce

jakież wielkie przyjęcie

po drodze -

Okutana

w chustę wiatrów

ze stopami w modlitwie piasku

który nigdy nie może powiedzieć Amen

musi bowiem

z płetwy w skrzydło

i dalej -

Chory motyl

wkrótce znów pozna morze -

Polonistyka. Innowacje

Numer 6, 2017 
Ten kamień

z inskrypcją muchy

oddał się w moje ręce -

Zamiast ojczyzny

trzymam przemiany świata - (SK, 89)

Po przeczytaniu przez nią wiersza przedstawiciel Akademii Sztokholmskiej powiedział:

Około dwudziestu lat temu, dzięki szwedzkiemu poecie, Hjalmarowi Gullbergowi, po raz pierwszy dowiedziałem się o losie pani i pani dzieła. Odkąd zamieszkała pani w Szwecji, mogę z panią rozmawiać w moim własnym języku. Ale to dzięki pani ojczystemu językowi - pani praca odzwierciedla historyczny dramat, w którym pani uczestniczyła. Pani liryczne i dramatyczne dzieło należy do wielkich lamentów literatury, ale uczucie smutku, które panią zainspirowało, jest wolne od nienawiści (https://www.nobelprize.org/nobel_prizes/literature/laureates/1966/sachs-speech-ty.html (dostęp 12.12.2017, przeł. J.R.).

Jej dzieło uznał za przesłanie pocieszenia dla wszystkich rozpaczających nad losem człowieka. Wyraził przekonanie, że oto spełniają się słowa Alfreda Nobla i Akademia przyznała nagrodę poezji zdolnej przynieść największe korzyści ludzkości. Wspomniał też przemówienie noblowskie Williama Faulknera, wcześniejsze o szesnaście lat. Padły w nim słowa: „Nie wierzę w koniec człowieka" ${ }^{\prime}$.

\section{Poezja w służbie pokojowi}

Homonimiczność słowa „pokój” pozwala odnosić je i do pomieszczenia, w którym można zamieszkać, i do globalnego porządku świata oraz spokoju duszy (Roszak 2017,4). Nelly Sachs, czytelniczka ksiąg Martina Bubera, musiała znać ten fragment Opowieści chasydów, w którym żydowski myśliciel pisał o nauczaniu Rabbiego Bunama:

Nasi mędrcy powiadają: „Szukaj pokoju w sobie”. Tylko w sobie, nigdzie indziej, można odnaleźć pokój. W psalmie powiedziano: „Nie ma pokoju w moich kościach na skutek mego grzechu". Dopiero kiedy człowiek ustanowi pokój w sobie, może go stanowić w świecie (Buber 2005, 245).

Jej wiersze wyrażają tęsknotę do świata bez wojen. Jeden z tomów zatytułowała $W$ mieszkaniach śmierci, bo po Szoa już na zawsze żyła z duchami zabitych podczas Zagłady. Utwory te należą do kanonu twórczości wychowującej do pokoju. Na marginesie lektur noblistki z 1966 roku zgłaszam więc $\mathrm{w}$ tym artykule postulat wykorzystania poezji na wszystkich szczeblach edukacji pokojowej.

\footnotetext{
${ }^{6}$ „I believe that man will not merely endure: he will prevail. He is immortal, not because he alone among creatures has an inexhaustible voice, but because he has a soul, a spirit capable of compassion and sacrifice and endurance. The poet's, the writer's, duty is to write about these things. It is his privilege to help man endure by lifting his heart, by reminding him of the courage and honor and hope and pride and compassion and pity and sacrifice which have been the glory of his past. The poet's voice need not merely be the record of man, it can be one of the props, the pillars to help him endure and prevail" (Frenz 1969).
} 
W tym kontekście proponuję lekturę wiersza Kleiner Frieden:

In der durchsichtigen Stunde

am Levkojengrab

im Abendrot trompetet Jenseits.

Gloriole des Palmenblattes

Wüstenoffenbarung der Einsamkeit.

Der Ahne Leben

im leuchtenden Andachtsbuch

ruhend auf Murmelbaches Schlummerrolle

und Muschel an das Ohr gelegt

mit Spieluhrmelodie.

O großer Ozean im kleinen Ohr!

O Menuett der Liebe

oblatenzartes Stundenbuch

auch das war Leben -

der gleiche Schlaf in schwarz Magie

und Dorn der die vergessene Rose

des Blutes

in Erinnerung sticht

gezähnter Blitz

in des Gewitters

Maskentanz

verdunkelnd

auf diese Elfenbeinküste (Sachs 1988, 284-285).

\section{Mały pokój}

W przezroczystej godzinie

na grobie lewkonii

w wieczornej czerwieni trąbi druga strona.

Aureola liścia palmowego

pustynne objawienie samotności.

Życie przodkini

w lśniącym modlitewniku

spoczywającym w mruczącym strumieniu zagłówka

i muszla przyłożona do ucha

z melodią pozytywki.

O potężny oceanie w maleńkim uchu!

O menuecie miłości

delikatna niczym opłatek księgo godzin

także to było życiem - 
ten sam sen w czerni magii

i cierń który przeszywa w pamięci

zapomnianą różę

krwi

zębaty piorun

w burzowym tańcu w

maskach

zaciemniając

na to Wybrzeże Kości Słoniowej (przeł. J.R.)

Polskie tłumaczenie tytułu wiersza wprowadza niepotrzebną dwuznaczność, której jednak trudno uniknąć. Wiąże się ona ze wspomnianą homonimicznością słowa pokój. Już pierwsza całostka daje wyobrażenie o sytuacji lirycznej: oto wieczorem kogoś odwiedzającego grób goździka (uschnięty kwiat na parapecie lub w wazonie?) nachodzą myśli eschatologiczne i poraża własna samotność. Dychotomia (ta strona, tamta strona, świat żywych, świat zgładzonych, prześladowcy, prześladowani) zostaje tu sprowadzona do skali prywatnej: wyłaniają się kształty kobiecego podmiotu i nieistniejącego "ty” („wy”). Zaczyna się rozpamiętywanie życia przodków, a więc, znając los Sachs, można stwierdzić, że zaczyna się rozpamiętywanie Zagłady. Kolejna strofoida tematyzuje akt przypominania, zarówno przez zbudowanie obrazu wsłuchania się w dźwięki w muszli, jak i przez echo tytułu Księgi godzin Rainera Marii Rilkego. Choć istnieje kwiatowa odmiana goździk poety, domyślać się można, że goździk symbolizuje w wierszu Sachs pierwszą i ostatnią miłość.

Poezja-pocieszycielka, poezja zainteresowana kondycją człowieczeństwa, przynosząca korzyści ludzkości, taka, która upomina się o wartości humanistyczne - przypomina, że pokój jest prawem człowieka i należy go pielęgnować. Betty Reardon z Columbia University za filary idealnej edukacji na rzecz pokoju uznała: oparcie na tym, co personalne, polityczne, pedagogiczne oraz związane z poezją (personal, political, pedagogical, poetic) (Reardon 2000, 31). Ponieważ bliskie jest mi przekonanie amerykańskiej badaczki, chciałabym podsumować artykuł, podkreślając możliwości pracy na rzecz pokoju z tekstami poetyckimi Nelly Sachs. Reardon wykładała: „Poezja jest ekspresją wszystkich form ludzkich emocji. Kultury, polityki i religii. Edukacja na rzecz pokoju to nasza wspólna poezja” („Poetry is the expression of all forms of human emotion. It transcends culture, politics and religion. Peace education is our common poetry", Reardon 2000, 31).

By wzbogacić edukację propokojową i praktykować tę koncepcję pedagogiczną, warto sięgać po literaturę będącą rezerwuarem pamięci, uczącą multikulturowości, otwarcia na drugiego, zabierającą w odległe zakątki planety, konfrontującą różne punkty widzenia, motywującą do działania na rzecz lepszego świata, po taką, która jest drogą do budowania pokoju, a więc do osiągania wewnętrznej i zewnętrznej harmonii, bo podsuwa narzędzia do rozwiązywania konfliktów, staje się nauką miłości i przyjaźni 
(także z Ziemią), zrozumienia, akceptacji, współpracy, braterstwa, moralności, wreszcie współczucia (Learning the Way of Peace 2001, 11).

Fran Schmidt i Alice Friedman budują obraz edukacji propokojowej, w której akcentują nadrzędność kategorii człowieczeństwa nad reprezentowaniem narodu czy religii:

pozwala znaleźć kreatywne i niedestruktywne sposoby rozstrzygania konfliktu i żyć w zgodzie ze sobą, z innymi i ich światem. Budowanie pokoju jest zadaniem każdego człowieka oraz wyzwaniem dla rodziny ludzkiej (Learning the Way of Peace, 2001, 11) ${ }^{7}$.

Po przeprowadzonym dwie dekady temu eksperymencie Arthur Aron ustalił, że zaledwie cztery minuty spędzone przez obcych ludzi na patrzeniu sobie w oczy zbliża ich i buduje między nimi relację opartą na empatii i bliskości. Ale empatię i bliskość może budować także intensywne spotkanie z tekstem literackim. Do czterominutowego, intensywnego zapatrzenia w czyjeś oczy daje się porównać właśnie lektura wiersza: krótkiego, zaledwie sugerującego znaczenie, komunikującego nie tylko słowem, ale także ciszą, którą niekiedy wnikliwie opisuje. Taki wiersz może zbudować przymierze z Nieznanym, pozbawić go stygmatyzacji, ewokować empatię, spróbować zgłębić jego naturę, zgłębiając się jednocześnie naturę ludzką. Minimalistyczne, eliptyczne wiersze Nelly Sachs osiągają wielki cel, mogą nauczać pokoju i tego, „aby prześladowani nie stali się prześladowcami” (SK, 27).

\section{Bibliografia}

Barańczak Stanisław, 2006, Wiersze zebrane, Kraków.

Bierezin Jacek, 1990, Tyle rzeczy, Paris.

Bower Kathrin M., 2000, Ethics and Remembrance in the Poetry of Nelly Sachs and Rose Ausländer, New York.

Buber Martin, 2005, Opowieści chasydów, Hertz P. (przeł.), Poznań-Warszawa.

Buryła Sławomir, 2016, Wokół Zagłady. Szkice o literaturze Holokaustu, Kraków.

Celan Paul, Sachs Nelly, 1994, Listy, Buras J.S. (wybór, przeł.), „Literatura na Świecie", nr 6.

Celan Paul, 1998, Przemówienie z okazji przyjmowania Nagrody Literackiej Wolnego Hanzeatyckiego Miasta Bremy, Przybylak F. (przeł.), w: Utwory wybrane, Krynicki R. (red.), Kraków.

Dinesen Ruth, 1992, Nelly Sachs. Eine Biographie, aus dem Dänischen von Gabriele Gerecke, Frankfurt am Main.

Elior Rachel, 2009, Mistyczne źródła chasydyzmu, Tomal M. (przeł.), Austeria, Kraków-Budapeszt.

\footnotetext{
${ }^{7}$ „Peace education is skill building. It empowers children to find creative and nondestructive ways to settle conflict and to live in harmony with themselves, others and their world. Peace building is the task of every human being and the challenge of the human family".
} 
Evelein Johannes F., 2014, Literary Exiles from Nazi Germany: Exemplarity and the Search for Meaning, New York.

Fioretos Aris, 2010, Flucht und Verwandlung. Nelly Sachs, Schriftstellerin, Berlin/Stockholm, aus dem Schwedischen von Paul Berf, Berlin.

Frankel Alona, 2007, Dziewczynka, Kwiatkowski L. (przeł.), Warszawa.

Frenz Horst (ed.), 1969, Nobel Lectures, Literature 1901-1967, Amsterdam.

Garloff Katja, 2005, Words from Abroad: Trauma and Displacement in Postwar German Jewish Writers, Detroit.

Hoyer Jennifer M., 2014, "The Space of Words”. Exile and Diaspora in the Works of Nelly Sachs, New York.

Karpowicz Tymoteusz, 1999, Słoje zadrzewne, Wrocław.

Kersten Paul, 1970, Die Metaphorik in der Lyrik von Nelly Sachs. Mit einer Wortkonkordanz und einer Nelly Sachs-Bibliographie, Hamburg.

Korte Hermann, 2012, Gedichte der deutschen Lyrik. Band 6: Von 1945 bis heute, Stuttgart.

Learning the Way of Peace. A Teacher's Guide to Peace Education, 2001, United Nations Educational, Scientific and Cultural Organization, New Delhi.

Lyrik nach Auschwitz. Adorno und die Dichter, 2012, hrsg. von Petra Kiedaisch, Stuttgart.

Martin Elaine, 2014, Nelly Sachs: The Poetics of Silence and the Limits of Representation, De Gruyter, Berlin.

Nancy Jean-Luc, 2004, Zakazana reprezentacja, Dziadek A. (przeł.), „Teksty Drugie", nr 5.

Oz Amos, 2010, Jak uleczyć fanatyka?, Sękalska D. (przeł.), Warszawa.

Patterson David, Berger Alan L. (ed.), 2002, Encyclopedia of Holocaust Literature, ed. Westport and London.

Reardon Betty, Higher Education for Peace. Report, Conference in Tromso, 4-6 May 2000.

Ronne Marta, 2011, A Foreigner to Her Mother Tongue, w: The Invasion of Books in Peripheral Literary Fields: Transmitting, Broomans P., Jiresch E (ed.), Groningen.

Rose Jonathan, 2008, The Holocaust and the Books: Destruction and Perseveration, Massachusetts.

Roszak Joanna, 2016, Umeblujmy sobie pokój, „Uczyć lepiej”, nr 5.

Sachs Nelly, 1988, Fahrt ins Staublose, Frankfurt am Main.

Sachs Nelly, 2006, Glühende Rätsel. Ausgewählte Gedichte. Roż̇arzone zagadki. Wiersze wybrane, Krynicki R. (wybór, przeł.), Kraków.

Sartorius Joachim, 2017, Zegar szronu, Krynicki R. (przeł.), Kraków.

Ubertowska Aleksandra, 2002, Aporie, skandale, wyrwy w tekście: etyka opowieści o Zagładzie, „Teksty Drugie”, nr 1/2 (73/74), s. 125-139.

Wójcik-Dudek Małgorzata, 2016, W(y)czytać Zagładę. Praktyki postpamięci $w$ polskiej literaturze XXI wieku dla dzieci i młodzieży, Katowice. 


\section{O Autorce:}

Joanna Roszak - adiunkt w Instytucie Slawistyki Polskiej Akademii Nauk, nauczycielka języka polskiego w Ogólnokształcącej Szkole Baletowej w Poznaniu. Poetka (lele, wewe, ladino, tego dnia, przyszli niedokonani) i inicjatorka wielu akcji dla młodzieży szkolnej i studenckiej. Współfundatorka i wiceprezeska Fundacji Józefa Rotblata. Ostatnio wydała Miejsce i imię. Poeci niemieckojęzyczni żydowskiego pochodzenia orazSłyszysz? Synagoga. Wychodzac spod poznańskiej synagogi przy Wronieckiej. Dwukrotnie nominowana do Nagrody im. Ireny Sendlerowej dla nauczycieli, którzy naprawiają świat. 